\title{
PENERAPAN AKUNTANSI PERTANGGUNGJAWABAN DENGAN ANGGARAN SEBAGAI ALAT PENGENDALIAN BIAYA PADA PT. GUNUNG NAGA MAS PADANG
}

\author{
Fakultas Ekonomi Universitas Ekasakti Padang \\ Jalan Veteran Dalam No. 26 B Padang (25113) Indonesia \\ ${ }^{1}$ Wira Pratiwi Asril ${ }^{2}$ Rina Asmeri ${ }^{3}$ Sunreni \\ 1'wirapratiwiasril@yahoo.com ${ }^{2}$ Rinaasmeri21@gmail.com ${ }^{3}$ Sunreni50@gmail.com
}

\begin{abstract}
Abstrak
Pada umumnya perusahaan bertujuan untuk memperoleh laba agar dapat bertahan dalam menghadapi persaingan pasar yang serba kompetitif. Salah satu upayanya adalah dengan menghasilkan produk yang berkualitas. Sehingga menjadikan persaingan yang semakin hari semakin meningkat oleh karena itu harus dilakukan perencanaan, pengendalian terhadap biaya-biaya yang dikeluarkan dan mengurangi biaya-biaya yang tidak efektif dalam kegiatannya. Penerapkan akuntansi pertanggungjawaban dapat dievaluasi dengan melihat sejauh mana manajemen perusahaan menjalankan syarat dan karakteristik akuntansi pertanggungjawaban yakni struktur organisasi, anggaran, pemisahan biaya,laporan pertanggungjawaban kode rekening, pusat pertanggungjawaban, standar pengukuran kinerja, pengukuran kinerja , serta pemberian penghargaan dan hukuman. Adapun tujuan dari penelitian ini adalah untuk mengetahui bagaimana penerapan akuntansi pertanggungjawaban dengan anggaran sebagai alat pengendalian biaya pada PT. Gunung Naga Mas Padang. Metode penelitian yang dilakukan dalam penelitian ini adalah metode analisis kualitatif dan metode analisis kuantitatif. Dari hasil penelitian menunjukkan bahwa penerapan akuntansi pertanggungjawaban belum berjalan dengan baik, dimana manajemen belum menerapkan sepenuhnya unsur-unsur akuntansi pertanggungjawaban dan tidak melakukan penelusuran secara mendalam atas penyimpangan yang terjadi.
\end{abstract}

Kata Kunci : Akuntansi Pertanggungjawaban, Anggaran, Pengendalian Biaya

\section{THE APPLICATION OF ACCOUNTING TO THE BUDGET AS A MEANS OF COST CONTROL GUNUNG NAGA MAS PADANG}

\begin{abstract}
In general, the company aims to make a profit in order to survive in the face of market competition which is too competitive. One of the efforts is to produce a quality product. So that makes the competition is constantly increasing therefore should do the planning, control of the costs incurred and reduces costs that are not effective in its activities. Applying accounting can be evaluated by looking at the extent to which the management company running the accounting requirements and characteristics of the organizational structure, budget, cost segregation, account code accountability report, the central accountability, performance measurement standards, performance measurement, as well as rewards and punishments. The purpose of this study was to determine how the application of accounting to the budget as a means of controlling costs at PT. Dragon Mountain Mas Padang. The research method used in this research is the method of qualitative analysis and quantitative analysis methods. The results showed that the application of accounting has not gone well, where management has not yet fully implementing the elements of accounting and no searches in depth for the irregularities that occurred.
\end{abstract}

Keywords: Responsibility Accounting, Budget Control 


\section{BAB I \\ PENDAHULUAN}

\subsection{Latar Belakang}

Pada umumnya perusahaan bertujuan untuk memperoleh laba agar dapat bertahan dalam menghadapi persaingan pasar yang serba kompetitif. Salah satu upayanya adalah dengan menghasilkan produk yang berkualitas. Sehingga menjadikan persaingan yang semakin hari semakin meningkat oleh karena itu harus dilakukan perencanaan, pengendalian terhadap biaya-biaya yang dikeluarkan dan mengurangi biaya-biaya yang tidak efektif dalam kegiatannya. Akuntansi pertanggungjawaban merupakan suatu sistem akuntansi yang digunakan untuk mengukur kinerja setiap pusat pertaggungjawaban sesuai dengan informasi yang dibutuhkan manajer untuk mengoprasikan pusat pertanggungjawaban, pusat pertanggungjawaban mereka sebagai bagian dari sistem pengendalian manajemen. Dalam menilai suatu perusahaan apakah sudah menerapkan akuntansi pertanggungjawaban atau belum maka bisa dilihat melalui syarat-syarat akuntansi pertanggungjawaban yakni struktur organisasi, anggaran, pemisahan biaya, dan laporan pertanggungjawaban. Serta karakteristik akuntansi pertanggungjawaban berupa pusat pertanggungjawaban, standar pengukuran kinerja, pengukuran kinerja manajer, dan pemberian penghargaan dan hukuman pada manajer suatu perusahaan.

\subsection{Perumusan Masalah}

Berdasarkan latar belakang masalah yang telah dikemukakan diatas maka penulis merumuskan masalah adalah "Bagaimana Penerapan Akuntansi Pertanggungjawaban Dengan Anggaran Biaya Produksi Sebagai Alat Pengendalian Biaya Produksi pada PT. Gunung Naga Mas Padang?".

\subsection{Tujuan dan Manfaat Penelitian}

Tujuan penelitian adalah untuk mengetahui penerapan akuntansi pertanggungjawaban dengan anggaran biaya produksi sebagai alat pengendalian biaya produksi pada PT. Gunung Naga Mas Padang. Sedangkan manfaat dari penelitian ini adalah Dapat dijadikan sebagai bahan masukan tentang pentingnya menambahkan akuntansi pertanggungjawaban dengan anggaran biaya produksi sebagai alat pengendalian biaya produksi.

\section{BAB II}

\section{TINJAUAN PUSTAKA}

\subsection{Akuntansi Pertanggungjawaban}

Akuntansi pertanggungjawaban adalah alat fundamental untuk pengendalian manajemen dan ditentukan melalui empat elemen penting, yaitu pemberian tanggung jawab, pembuatan ukuran kinerja atau benchmarking, pengevaluasian kinerja, dan pemberian penghargaan. Akuntansi pertanggungjawaban bertujuan mempengaruhi perilaku dalam cara tertentu sehingga seseorang atau kegiatan perusahaan akan disesuaikan untuk mencapai tujuan bersama.

\subsection{Karakteristik Akuntansi Pertanggungjawaban}

Menurut Mulyadi (2010:191), yaitu:

1. Adanya identifikasi pusat pertanggungjawaban.

Akuntansi pertanggungjawaban mengidentifikasikan pusat pertanggungjawaban sebagai unit organisasi seperti departemen, keluarga produk, tim kerja atau individu.

2. Standar ditetapkan sebagai tolak ukur kinerja manajer yang bertanggung jawab atas pusat pertanggungjawaban tertentu. 
Setelah pusat pertanggungajawaban diidentifikasi dan ditetapkan, sistem akuntansi pertanggungjawaban menghendaki ditetapkannya biaya standar sebagai dasar untuk menyusun anggaran.

3. Kinerja manajer diukur dengan membandingkan realisasi dengan anggaran.

Pelaksanaan anggaran merupakan penggunaan sumber daya oleh manajer pusat pertanggungjawaban dalam mewujudkan sasaran yang ditetapkan dalam anggaran. Penggunaan sumber daya ini diukur dengan informasi akuntansi pertanggungjawaban dalam mencapai sasaran anggaran.

4. Manajer secara individual diberi penghargaan atau hukuman berdasarkan kebijakan manajemen yang lebih tinggi

Sistem penghargaan dan hukuman dirancang untuk memacu para manajer dalam mengelola biaya untuk mencapai target standar biaya yang dicantumkan dalam anggaran.

\subsection{Syarat-syarat Akuntansi Pertanggungjawaban}

Agar sistem akuntansi pertanggungjawaban dapat diterapkan dan dilaksanakan dengan baik oleh suatu organisasi perusahaan, syarat-syarat yang harus dipenuhi menurut Mulyadi (2010:412), sebagai berikut:

1. Struktur organisasi yang menetapkan secara tegas sesuai wewenang dan tanggung jawab setiap tingkatan manajemen.

2. Anggaran biaya disusun menurut pusat pertanggungjawaban.

3. Penggolongan biaya sesuai dengan dapat tidaknya dikendalikan oleh manajer yang pusat pertanggungjawaban.

4. Terdapat susunan kode rekening perusahaan yang berkaitan dengan kewenangan pengendalian pusat pertanggungjawaban.

5. Sistem pelaporan biaya kepada manajer yang bertanggungjawab

\subsection{Pusat Pertanggungjawaban}

Menurut Henry Simamora (2012:255) pusat pertanggungjawaban merupakan unit organisasi yang dipimpin oleh seorang manajer yang bertanggungjawab atas aktivitas yang dilakukannya. Hongren (2012:12) menyataan bahwa pertanggungjawaban acconting mengidentifikasi bagian dari organisasi yang mempunyai tanggung jawab untuk setiap tujuan, mengembangkan ukuran dan target untuk dicapai, dan menciptakan laporan ukuran oleh bagian kecil dari organisasi atau pusat pertanggungjawaban.

Pusat pertanggungjawaban dimaksudkan untuk membatu mengimplementasikan rencana manajemen puncak. Dalam kaitan ini, organisasi terdiri dari kumpulan pusat pertanggungjawaban. Keseluruhan pusat pertanggungjawaba ini membentuk jenjang hierarki dalam organisasi tersebut.

\subsection{Jenis-jenis Pusat Pertanggungjawaban}

Ada empat jenis pusat pertanggungjawaban, digolongkan menurut sifat input dan/ output moneter yang diukur untuk tujuan pengendalian (Anthony dan Govindarajan, (2011:175) sebagai berikut :

1. Pusat pendapatan

Pusat pendapatan merupakan unit pemasaran/ penjualan yang tak memiliki wewenang untuk menetapkan harga jual dan tidak bertanggungjawab atas harga pokok penjualan dari barangbarang yang mereka pasarkan.

2. Pusat biaya

Pusat biaya adalah pusat pertanggungjawaban yang inputnya diukur secara moneter, namun output tidak.

3. Pusat laba

Ketika kinerja finansial suatu pusat pertanggungjawaban diukur dalam ruang lingkup laba (yaitu, selisih antara pendapatan dan biaya), maka pusat ini disebut sebagai pusat laba (profit center). 
4. Pusat investasi

Di unit usaha yang lain, laba dibandingkan dengan aktiva yag digunakan untuk menghsilkan laba tersebut. Pusat pertanggungjawaban ini disebut sebagai pusat investasi. Ukuran prestasi manajer pusat investasi dapat berupa rasio antara laba dengan investasi yang digunakan untuk memperoleh laba tersebut.

\subsection{Hubungan Pusat Pertanggungjawaban dengan Struktur Organisasi}

Struktur organisasi merupakan syarat utama yang harus di penuhi dalam menerapkan sistem akuntansi pertanggungjawaban dan penentuan pusat-pusat pertanggungjawaban dalam suatu organisasi. Menurut Supriyono (2011) terdapat dua tipe struktur organisasi yang berkaitan dengan pusat-pusat pertanggungjawaban, yaitu:

1. Organisasi Fungsional

Pusat-pusat pertanggungjawaban digambarkan dalam pembagian fungsi organisasi yaitu fungsi produksi, fungsi penjualan (pemasaran) dan fungsing administrasi.

2. Organisasi Divisional

Pada organisasi ini, pembagian organisasi didasarkan pada divisi-divisi bertanggung jawab bagi seluruh fungsi yang ada dalam produksi pemasaran sebuah produk.

\subsection{Anggaran}

Menurut William K. Carter (2009:13) anggaran adalah pernyataan yang terkualifikasi dan tertulis dari rencana manajemen. Sedangkan menurut Anthony, dan kawan-kawan (dikutip oleh Diana Putri,2005), berdasarkan pusat-pusat pertanggungjawaban, anggaran dibagi menjadi tiga jenis, yaitu:

1. Anggaran biaya

Anggaran biaya dapat dibagi ke dalam dua macam, yaitu:

1) Anggaran yang menyangkut pengeluaran terukur (engineered expenses). Dalam pusat tanggung jawab, dimana keluaran dapat diukur.

2) Anggaran yang menyangkut pengeluaran diskresioner (discretionary expenses) di pusat tanggung jawab, di mana keluaran tidak dapat diukur.

2. Angggaran pendapatan

Anggaran pendapatan mempunyai karakteristik berikut,yaitu:

1) Anggaran ini dirangcang untuk mengukur efektifitas pemasaran.

2) Manajer pemasaran tidak dapat dituntut untuk sepenuhnya bertanggung jawab atas pencapaian sasaran yang dianggarkan seperti halnya dengan anggaran biaya.

3. Anggaran laba Anggaran laba divisi digunakan oleh manajemen puncak:

1) Untuk mereview kerja keuangan perusahaan total yang diharapkan untuk tahun mendatang dan untuk mengambil tindakan tertentu bila unjuk kerja tersebut tidak memuaskan.

2) Untuk merencanakan dan mengkoordinasikan kegiatan keseluruhan perusahaan

3) Untuk berperan serta dalam perencanaan divisi

4) Untuk ikut mengendalikan, tidak-tidaknya sebagian divisi anggran disusun untuk memenuhi berbagai tujuan tertentu.

2011):

Penyusunan anggaran operasi mempunyai empat tujuan utama (Anthony dan Govindarajan,

1. Untuk menyesuaikan rencana strategis.

2. Untuk membantu mengkoordinasikan aktivitas dari beberap bagian organisasi.

3. Untuk menugaskan tanggung jawab kepada manajer, untuk mengotorisasikan jumlah yang berwenang untuk mereka gunakan, dan untuk menginformasikan kepada merekamengenai kinerja yang diharapkan dari mereka.

4. Untuk memperoleh komitmen yang merupakan dasar untuk mengevaluasi kinerja aktual manajer. 
Menurut Hansen dan Mowen (2010:424), sebuah sistem penganggaran memberikan beberapa manfaat untuk suatu organisasi:

1. Memaksa para manajer untuk melakukan perencanaan.

2. Menyediakan informasi yang dapat diguanakan untuk memperbaiki pengambilan keputusan.

3. Menyediakan standar evaluasi kerja.

4. Memperbaiki komunikasi dan koodinasi.

\subsection{Pengendalian Biaya}

\subsubsection{Pengertian Biaya}

Biaya merupakan pengorbanan yang dapat diukur dengan satuan tertentu dan jangka waktu atau masa manfaat dari pengorbanan tersebut. Pengorbanan yang menghasilkan manfaat dapat disebut sebagai biaya, sedangkan pengorbanan yang tidak menghasilkan manfaat dianggap sebagai pemborosan (kerugian) yang diderita oleh perusahaan.

\subsubsection{Konsep Pengendalian}

Fungsi pengendalian merupakan fungsi yang penting untuk menentukan proses manajemen, sehingga harus dilakukan sebaik mungkin. Pada umumnya perusahaan melakukan pengawasan biaya yang tidak lain agar dapat mengendalikan biaya yang terjadi dalam menjalankan kegiatan sehingga dapat berjalan dengan efektif dan efesien.

\subsubsection{Penerapan Akuntansi Pertanggungjawaban dengan Anggaran sebagai Alat Pengendalian Biaya}

Informasi akuntansi pertanggungjawaban merupakan informasi yang penting dalam proses perencanaan dan pengendalian aktivitas perusahaan, karena informasi tersebut menekankan hubungan antara informasi dengan manajer yang bertanggungjawab terhadap perencanaan dan realisasinya. Pengendalian dapat dilakukan dengan cara memberikan peran bagi setaip manajer untuk merencanakan pendapatan dan/ atau biaya menjadi tangung jawabnya, dan kemudian menyajikan informasi realisasi pendapatan atau biaya tersebut menurut manajer yang bertanggungjawab.

\subsection{Penelitian Terdahulu}

Tabel 2.1 Penelitian Terdahulu

\begin{tabular}{|c|l|l|l|}
\hline No & Peneliti & \multicolumn{2}{|c|}{ Judul Hasil Penelitian } \\
\hline 1 & $\begin{array}{l}\text { Stefanly dan } \\
\text { Tirayoh } \\
(2015)\end{array}$ & $\begin{array}{l}\text { Penerapan akuntansi } \\
\text { pertanggungjawaban dengan } \\
\text { anggaran sebagai alat } \\
\text { pengendalian biaya pada PT. } \\
\text { Gotrans Logistic Cabang Manado. }\end{array}$ & $\begin{array}{l}\text { Penerapan } \\
\text { pertanggungawaban belum } \\
\text { bejalan dengan baik dan tidak } \\
\text { melakukan penelusuran secara } \\
\text { mendalam atas penyimpangan } \\
\text { yang terjadi. }\end{array}$ \\
\hline 2 & $\begin{array}{l}\text { Fairus, dkk } \\
(2015)\end{array}$ & $\begin{array}{l}\text { Analisis Penerapan Akuntansi } \\
\text { pertanggungjawaban dengan } \\
\text { Anggaran sebagai Alat } \\
\text { Pengendalian Biaya pada PT. } \\
\text { Surya Sakti Utama Surabaya. }\end{array}$ & $\begin{array}{l}\text { Akuntansi pertanggungjawaban } \\
\text { masih belum memadai karena } \\
\text { belum memenuhi indikator- } \\
\text { indikator penerapan laporan } \\
\text { pertanggungawaban sebagai } \\
\text { bukti adanya tanggung jawab } \\
\text { pada setiap divisi yang terkait. }\end{array}$ \\
\hline
\end{tabular}




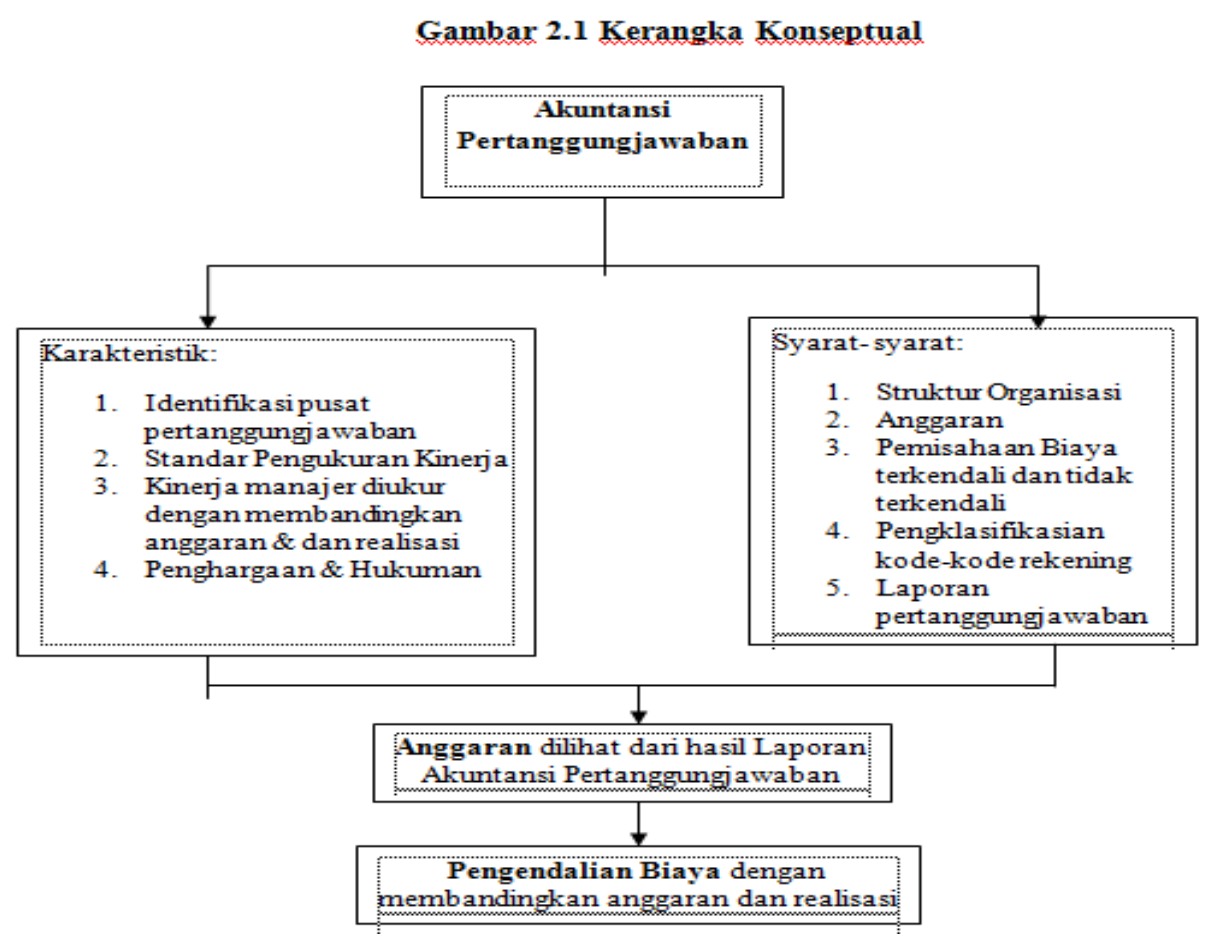

\subsection{Hipotesis}

Berdasarkan uraian latar belakang dan landasan teori maka peneliti menarik hipotesis yaitu, "Diduga terdapat perbedaan anggaran biaya produksi dengan laporan akuntansi pertanggungjawaban biaya produksi”.

BAB III

\section{METODE PENELITIAN}

\subsection{Sejarah Umum PT. Gunung Naga Mas}

PT. Gunung Naga Mas adalah sebuah perusahaan milik swasta nasional yang berdiri sejak tanggal 11 Juli 2012 yang beralamat di Jalan Kampung Pinang Kav. B, Kelurahan Lambung Bukit, Kecamatan Pauh, Kotamadya Padang, Profinsi Sumatera Barat. PT. Gunung Naga Mas, nama perusahaan yang ditetapkan oleh Owner dan Direksi berdasarkan letak posisi pabrik yang berada disekitar wilayah Gunung Nago. Nilai bisnis yang diharapkan atas ditetapkannya PT. Gunung Naga Mas untuk industri Air Minum Dalam Kemasan (AMDK) dan Air Minum Berasa (AMB). Air tersebut diambil dari sumur bor dengan kedalaman 100 meter dan telah diuji keabsahaannya serta memiliki legalitas resmi dari pemerintahan Kota Padang. Sistem pengolahan memakai Water Treatment Multi Fungsi dengan desintektan dan teknologi modern serta dilakukan pengemasan melalui mesin pengisian meliputi mesin pengisian Cup $240 \mathrm{ml}$, mesin pengisian Botol $380 \mathrm{ml}$, mesin pengisian Botol $600 \mathrm{ml}$, mesin pengisian Botol $1500 \mathrm{ml}$ dan mesin pengisian Galon 19 liter. PT. Gunung Naga Mas memproduksi Air Minuman Dalam kemasan (AMDK) perdana secara komersial 
pada tahun 2014 dengan wilayah pemasaran Sumatera meliputi Provinsi Sumatera Barat, Riau, Jambi, Bengkulu, Sumatera Utara, Sumatera Selatan dan Lampung.

PT. Gunung Naga Mas telah melakukan persiapan untuk mendapatkan sertifikat ISO 9001:2008 untuk sistem manajemen mutu dari lembaga yang terakreditasi oleh Komite Akreditasi Nasional (KAN). Sertifikat tersebut digunakan untuk menjamin sistem manajemen mutu yang diterapkan oleh PT. Gunung, sehingga produk yang dikeluarkan dijamin layak dikonsumsi oleh masyarakat. Kemudian, dengan persiapan dan persyaratan tersebut PT. Gunung Naga Mas mendapatkan Nomor SNI yaitu SNI 01-3553-200.

\subsection{Metodologi Penelitian}

\subsubsection{Metode Pengumpulan Data}

Metode pengumpulan data yang digunakan oleh penulis dalam penelitian ini adalah:

\section{Penelitian Kepustakaan (Library Research)}

Yaitu meliputi pengumpulan data teori-teori dan bahan melalui buku-buku, artikel yang mempunyai hubungan dengan permasalahan dengan yang dibahas dalam penulisan ini.

2. Penelitian Lapangan (Field Research)

Penelitian yang dilakukan dengan cara wawancara dan pengumpulan data dan informasi yang diperoleh langsung dari PT.Gunung Naga Mas Padang.

\subsubsection{Teknik Pengumpulan Data}

Guna memperoleh data dan keterangan yang diperlukan dalam penelitian skripsi, teknik pengumpulan data yang penulis lakukan dalah sebagai berikut:

1. Wawancara (interview), yaitu dengan melakukan tanya jawab secara lisan dengan pihak-pihak yang berwewenang dalam perusahaan untuk memperoleh data atau informasi yang ada hubungannya dengan masalah.

2. Dokumentasi, yaitu data yang diperoleh melalui laporan tahunan dari jumlah customer yang ada pada perusahaan serta buku-buku yang berkaitan dengan pemasaran.

\subsubsection{Jenis dan Sumber Data}

Jenis dan sumber data yang digunakan peneliti adalah:

1. Data primer yaitu data atau segala sesuatu yang diperoleh dari hasil pengamatan dan dicatat oleh peneliti langsung dari perusahaan yang menjadi objek penelitian. Data ini diperoleh dengan cara melakukan wawancara.

2. Data sekunder yaitu data yang diperoleh secara tidak langsung atau melalui pihak lain, atau laporan historis yang telah disusun dalam arsip yang dipublikasikan atau tidak.

\subsubsection{Definisi Operasional Variabel}

1. Akuntansi pertanggungjawaban

Yaitu alat fudamental untuk pengendalian manajemen dan ditentukan melalui empat elemen penting, yaitu pemberiam tanggung jawab, pembuatan ukuran kinerja atau benchmarking, pengevaluasian kinerja dan pemberian penghargaan(Hansen dan Mowen,2009).

2. Anggaran

merupakan suatu alat yang digunakan dalam melaksanakan proses perencanaan dan pengendalian manajemen serta komitmen dari setiap manajemen dinyatakan dalam satuan moneter (Stefanly dan Tirayoh, 2015).

3. Pengendalian biaya

Adalah tindakan yang dilakukan untuk mengarahkan aktivitas agar tidak menyimpang dengan tujuan yang telah ditetapkan sebelumnya (Stefanly dan Tirayoh, 2015). 


\subsubsection{Metode Analisis Data}

Metode analisis data yang dipakai dalam penelitian ini adalah metode analisis kualitatif dan metode analisis kuantitatif.

Yang mana peneliti menggunakan analisis kualitatif deskriptif yang tujuannya untuk mendapatkan gambaran yang lebih jelas dan terperinci mengenai suatu keadaan berdasarkan data atau informasi yang telah didapatkan, kemudian dikumpulkan, diklasifikasi, dan diinterprestasikan sehingga didapatkan informasi yang diperlukan untuk menganalisa masalah yang ada, akhirnya sampai pada suatu kesimpulan yang relevan dengan teori.

Sedangkan analisis kuantitatif, peneliti menggunakan uji wilcoxon dengan perbandingan antara anggaran dan laporan akuntansi pertanggungjawaban biaya produksi agar mengetahui penerapan akuntansi pertanggungjawaban dengan anggaran sebagai alat pengendalian biaya pada PT. Gunumg Naga Mas Padang.

Menurut Agussalim Manguluang, (2013:109) uji ini merupakan pengembangan dari uji tanda, dimana bukan hanya tanda yang diperhatikan tetapi nilai selisihnya juga dibutuhkan dari $\left(\mathrm{X}_{1}-\mathrm{Y}_{1}\right)$. Cara yang dapat dilakukan untuk menyelesaikan uji ini adalah sebagai berikut:

a. Beri nomor urut untuk setiap harga mutlak selisih $\left(\mathrm{X}_{1}-\mathrm{Y}_{1}\right)$ harga mutlak terkecil diberi nomor urut atau rank 1, harga mutlak selisih berikutnya diberi nomor urut 2 dan akhirnya harga mutlak terbesar diberi nomor urut $\mathrm{N}$.

b. Untuk tiap nomor urut berikan pada tanda yang terdapat dari selisih $\left(\mathrm{X}_{1}-\mathrm{Y}_{1}\right)$.

c. Hitunglah jumlah nomor urut yang bertanda positif dan juga jumlah nomor urut yang bertanda negatif.

d. Untuk jumlah nomor urut pada poin C ) diatas, ambillah jumlah yang harga mutlaknya paling kecil, sebutlah jumlah ini sama dengan J. Jumlah $\mathrm{J}$ inilah yang dipakai untuk menguji hipotesis.

\subsubsection{Metode Pengujian Hipotesis}

Menurut Agussalim Manguluang untuk menguji apakah hipotesis yang diajukan dapat diterima atau ditolak maka diperlukan perbandingan antara hasil uji wilcoxon dengan hasil uji tabel sesuai lampiran satu dengan menggunakan $\alpha=5 \%$.

Hipotesis akan diuji adalah sebagai berikut:

$\mathrm{H}_{0}$ : terdapat perbedaan anggaran biaya produksi dengan laporan akuntansi pertanggungjawaban biaya produksi.

$\mathrm{H}_{\mathrm{A}}$ : tidak ada perbedaan anggaran biaya produksi dengan laporan akuntansi pertanggungjawaban biaya produksi.

Dengan ketentuan : $\mathrm{H}_{0}$ ditolak dan $\mathrm{H}_{\mathrm{A}}$ diterima, apabila $\mathrm{J}_{\text {-hitung }} \leq$

$\mathbf{J}_{\text {-tabel }}$ dan sebaliknya $\mathrm{H}_{0}$ diterima dan $\mathrm{H}_{\mathrm{A}}$ ditolak apabila $\mathrm{J}_{\text {-hitung }}>\mathrm{J}_{\text {-tabel. }}$.

\section{BAB IV}

\section{PEMBAHASAN}

\subsection{Penerapan Akuntansi Pertanggungjawaban Dengan Anggaran Sebagai Alat Pengendalian Biaya}

Dengan membandingkan antara teori-teori yang telah ada dengan data-data yang didapat dari studi kasus maka dapat dikatakan bahwa penerapan akuntansi pertanggungjawaban pada PT. Gunung Naga Mas Padang belum memadai. Suatu penerapan akuntansi pertanggungjawaban dapat dikataka memadai jika telah memenuhi syarat dan karakteristik akuntansi pertanggungjawaban. Dalam pembahasan ini dapat diihat bahwa perusahaan belum melakukan pemisahan biaya terkendali dan biaya tidak terkendali.

Dengan tidak adanya pemisahan biaya terkendali dan tidak terkendali, maka perusahaan tidak dapat melakukan pengendalian biaya dengan baik. Anggran yang telah ditetapkan perusahaan tidak 
dapat digunakan untuk mengukur kinerja manajer. Selain itu, laporan pertanggungjawaban juga tidak mencerminkan besarnya biaya yang menjadi tanggung jawab manajer. Manajer hanya dimintai pertanggungjawaban atas biaya-biaya yang dapat dikendalikan saja.

Sedangkan pengendalian biaya dapat dikatakan baik jika telah memenuhi kelayakan pengendalian biaya secara memadai dan efisien. Dalam hai ini PT. Gunung Naga Mas Padang belum dapat melakukan pengendalian biaya dengan baik karena tidak adanya pemisahan biaya terkendali dan biaya tidak terkendali sehingga sulit dilakukan analisis yang mendalam mengenai penyimpagan biaya yang terjadi.

Dalam penelitian ini anggaran digunakan sebagai informasi akuntansi pertanggungjawaban. Dengan menganalisis anggaran tersebut, dapat diketahui efisiensi dari pengendalian biaya yag telah dilakukan perusahaan. Realisasi biaya yang terjadi dibandingkan dengan anggaran yang telah ditetapkan sebelumnya.

\subsubsection{Dilihat dari karakteristik akuntansi pertanggungjawaban sebagai berikut:}

1. Pusat pertanggungjawaban

Dari hasil penelitian pada PT. Gunung Naga Mas Padang, yang pusat pertanggungjawabannya pada pusat biaya, dimana manajernya diberi tanggung jawab untuk mengendalikan biaya yang dikeluarkan dan juga untuk mengambil keputusan yang mempengaruhi biaya tersebut.

2. Standar kinerja

Berdasarkan penelitian yang dilakukan pada PT. Gunung Naga Mas Padang telah menetapkan beberapa standar untuk menilai kinerja para manajernya. Untuk menilai kinerja manager pusat pertanggungjawaban, dilakukan perbandingan antara realisasi biaya dengan anggaran biaya yang terdapat pada laporan pertanggungjawaban.

3. Pengukuran kinerja

Hasil penelitian menunjukkan pada PT. Gunung Naga Mas Padang, terdapat laporan pertanggungjawaban berupa laporan realisasi anggaran yang dapat digunakan untuk mengukur kinerja manager. Dengan adanya jenis laporan seperti itu, maka kinerja manager dapat diukur oleh perusahaan.

4. Pemberian penghargaan dan hukuman

Pada PT. Gunung Naga Mas Padang, manager yang kinerjanya baik akan diberikan penghargaan berupa premi maupun promosi jabatan. Sementara jika kinerja manager kurang baik maka akan diberikan peringatan atau teguran.

\subsubsection{Dilihat dari syarat-syarat akuntansi pertanggungjawaban sebagai berikut:}

\section{Struktur organisasi}

Hasil penelitian menunjukkan PT. Gunung Naga Mas Padang secara tegas telah menetapkan wewenang dan tanggung jawab tiap tingkatan manajemen. Struktur organisasi yang dimiliki oleh PT. Gunung Naga Mas Padang ini menganut sistim organisasi garis. Dimana dalam bagan organisasinya terlibat ada kesatuan komando karena kepemimpinan berada ditangan satu orang dan setiap bawahannya hanya bertanggungjawab terhadap satu orang pemimpin saja.

2. Anggaran

Berdasarkan penelitian yang dilakukan, PT. Gunung Naga Mas Padang mengajukan anggaran yang akan digunakan untuk kegiatan perusahaan kepada PT. Gunung Naga Mas pusat. Pengajuan anggaran bertujuan untuk mengetahui jumlah dana yag dibutuhkan perusahaan cabang dalam membiayai seluruh operasional yang akan dilaksanakan dan sebagai alat bantu bagi manajemen dalam mencegah terjadinya penyimpangan-penyimpangan terhadap penggunaan dana perusahaan. Dengan demikian dapat dilihat bahwa PT. Gunung Naga Mas Padang telah menetapkan anggaran dalam penyusunan rencana kerja. 


\section{3, Biaya terkendali dan tidak terkendali}

Dari hasil penelitian menunjukkan penerapan akuntansi pertanggungjawaban pada PT. Gunung Naga Mas Padang belum memadai atau belum berjalan dengan baik. Suatu penerapan akuntansi pertaggungjawaban dapat dikatakan memadai jika telah memenuhi syarat akuntansi pertanggungjawaban.

4, Klasifikasi dan Kode Rekening

Berdasarkan hasil penelitian yang dapat dilakukan, dapat dikatakan bahwa PT. Gunung Naga Mas Padang telah melakukan pengkodean rekening biaya pada laporan pertanggungjawaban. Klasifikasi dan kode rekening berguna untuk menyadiakan identifikasi ringkas, mempermudah pencarian rekening yag diinginkan, mempermudah pencatatan dan penyimpanan data.

5, Laporan pertanggungjawaban

Dari hasil penelitian pada PT. Gunung Naga Mas Padang telah membuat laporan pertanggungjawaban berupa laporan realisasi anggaran. Pada laporan pertanggungjawaban dapat dilihat berapa besarnya perbandingan antara anggaran dengan realisasinya serta selisihnya.

Selain karakteristik dan syarat-syarat akuntansi pertanggungjawaban untuk melihat bagaimana penerapan akuntansi pertanggungjawaban dengan anggaran sebagai alat pengendalian biaya pada PT. Gunung Naga Mas Padang, Untuk lebih jelasnya tentang laporan akuntansi pertanggungjawaban yang ada di PT. Gunung Naga Mas Padang peneliti menggunakan uji wilcoxon dimana membandingkan antara anggaran yang digunakan dalam menjalankan operasional perusahaan dengan laporan pertanggungjawaban atas anggaran yang dilakukan pada biaya produksi.

Sedangkan analisis kuantitatif digunakan untuk menguji adanya penyimpangan atau selisih-selisih yang terjadi pada laporan akuntansi pertanggungjawaban biaya produksi dengan menggunakan uji wilcoxon.

Uji ini merupakan pengembangan dari uji tanda, dimana bukan hanya tanda yang diperhatikan tetapi nilai selisihnya juga dibutuhkan dari $\left(\mathrm{X}_{1}-\mathrm{Y}_{1}\right)$, sebagai berikut:

Tabel 4.1

\begin{tabular}{|c|c|c|c|c|c|c|c|}
\hline \multirow[t]{3}{*}{ No } & \multirow{3}{*}{\begin{tabular}{l|}
\multicolumn{2}{|c|}{ URAIAN } \\
By Produksi \\
Langsung
\end{tabular}} & \multicolumn{2}{|c|}{2013} & \multirow[t]{3}{*}{ Beda } & \multirow{3}{*}{$\begin{array}{l}\mathrm{Ra} \\
\mathbf{n k}\end{array}$} & \multicolumn{2}{|c|}{ Tanda rank } \\
\hline & & Anggaran & Realisasi & & & + & - \\
\hline & & & & & & & \\
\hline 1 & $\begin{array}{l}\text { Pemakaian } \\
\text { Bahan Baku }\end{array}$ & 871.200 .000 & 897.332 .000 & -26.132 .000 & -12 & & -12 \\
\hline 2 & Upah Langsung & 75.019 .000 & 75.314 .750 & -295.750 & -7 & & -7 \\
\hline 3 & $\begin{array}{l}\text { By Produksi } \\
\text { Tak langsung }\end{array}$ & 136.800 .000 & 154.322 .000 & -17.522 .000 & -11 & & -11 \\
\hline 4 & $\begin{array}{ll}\text { Upah } & \text { Tak } \\
\text { langsung }\end{array}$ & 68.275 .000 & 68.376 .000 & -101.000 & 5 & 5 & \\
\hline 5 & $\begin{array}{l}\text { Pemeliharaan } \\
\text { Bangunan }\end{array}$ & 5.000 .000 & 4.562 .610 & 437.390 & 9 & 9 & \\
\hline 6 & $\begin{array}{l}\text { Pemeliharaan } \\
\text { Mesin }\end{array}$ & 3.000 .000 & 2.347 .233 & 652.767 & 10 & 10 & \\
\hline 7 & $\begin{array}{l}\text { Pemeliharaan } \\
\text { Kendaraan } \\
\text { Operasional }\end{array}$ & 2.500 .000 & 2.111 .210 & 388.790 & 8 & 8 & \\
\hline 8 & Listrik & 3.600 .000 & 3.679 .100 & -79.100 & -2 & & -2 \\
\hline 9 & Air dalam Tanah & 1.500 .000 & 1.500 .000 & 0 & 1 & 1 & \\
\hline 10 & $\begin{array}{l}\text { Penyusutan } \\
\text { Bangunan }\end{array}$ & 4.231 .652 & 4.132 .200 & 99.452 & 3 & 3 & \\
\hline 11 & $\begin{array}{l}\text { Penyusutan } \\
\text { Mesin }\end{array}$ & 4.100 .000 & 4.000 .000 & 100.000 & 4 & 4 & \\
\hline 12 & $\begin{array}{l}\text { Penyusutan } \\
\text { Kendaraan } \\
\text { Operasional }\end{array}$ & 4.080 .000 & 3.811 .350 & 268.650 & 6 & 6 & \\
\hline & & & & & & 46 & -32 \\
\hline
\end{tabular}

Sumber: diolah oleh penulis 
Ada beberapa perbedaan anggaran dengan hasil laporan akuntansi pertanggungjawaban yang dilakukan, hal ini dikarnakan besarnya biaya dan kondisi ekonomi yang sedang terjadi pada saat melakukan transaksi. Adapun perbedaan terjadi pada biaya bahan baku, biaya tenaga kerja, dan biaya lainnya. Namun dari hasil perhitungan pada tabel di atas maka diperoleh nilai terkecil dari perhitungan wilcoxon, nilai terkecil diperoleh pada rank negatif dimana sebesar 32 , hal tersebut bisa disimpulkan bahwa yang menjadi $J_{\text {-hitung }}=32$. Sedangkan $n=12$ untuk $J_{\text {. }}$ tabel diambil dari tabel uji wilcoxon dengan tingkat kesalahan 0,05 diperoleh yaitu 14 . Hal ini dapat disimpulkan bahwa pada tahun $2013 \mathrm{H}_{0}$ diterima dan $\mathrm{H}_{\mathrm{A}}$ ditolak karena $\mathrm{J}_{\text {-hitung }}$ lebih besar dari pada $\mathrm{J}_{\text {-tabel }}$ yaitu $\mathrm{J}_{\text {-hitung }}=32 \geq \mathrm{J}_{\text {-tabel }}=14$ dengan demikian hipotesis diterima.

Dengan ketentuan sebagai berikut:

$\mathrm{H}_{0} \quad$ : terdapat perbedaan anggaran biaya produksi dengan laporan akuntansi pertanggungjawaban biaya produksi.

$\mathrm{H}_{\mathrm{A}} \quad$ : tidak ada perbedaan anggaran biaya produksi dengan laporan akuntansi pertanggungjawaban biaya produksi.

Tabel 4.2

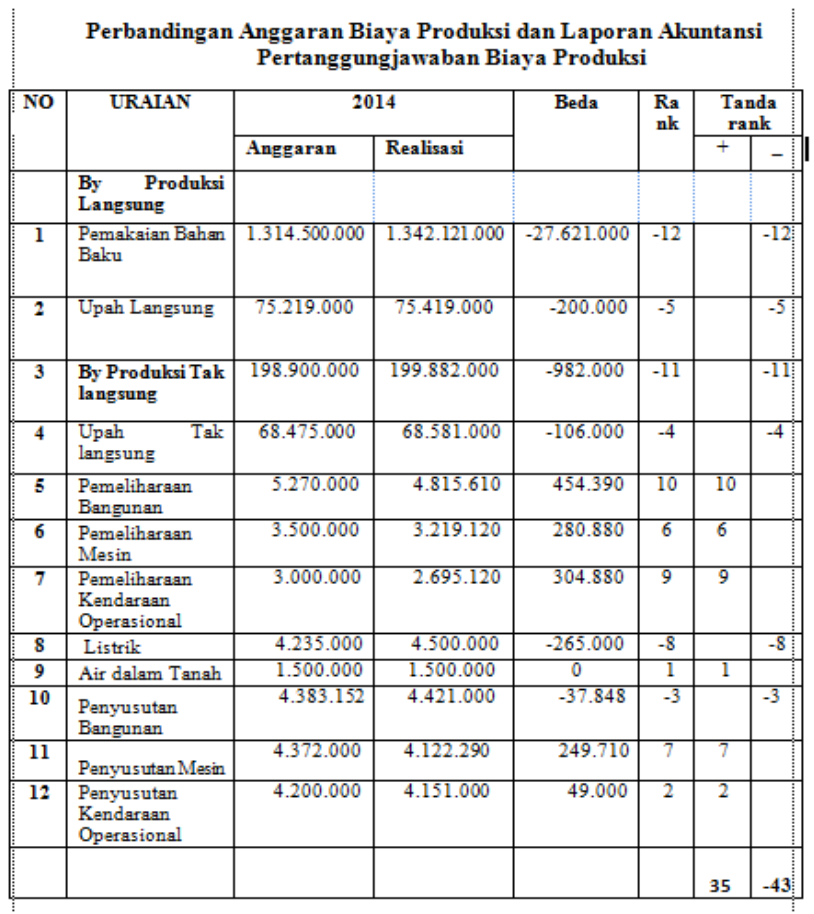

Sumber: diolah oleh penulis

Mempengaruhi peningkatan produksi, maka mengharuskan karyawan untuk lembur sedangkan dalam hal ini biaya untuk lembur tidak dianggarkan sehingga biaya realisasi lebih besar dari yang dianggarkan. Adapun perbedaan terjadi pada biaya bahan baku, biaya tenaga kerja, listrik dan biaya lainnya. Namun dari hasil perhitungan pada tabel di atas maka diperoleh nilai terkecil dari perhitungan wilcoxon, nilai terkecil diperoleh pada rank negatif dimana sebesar 43, hal tersebut bisa disimpulkan bahwa yang menjadi $\mathrm{J}_{\text {-hitung }}=43$. Sedangkan $\mathrm{n}=12$ untuk $\mathrm{J}_{\text {-tabel }}$ diambil dari tabel uji wilcoxon dengan tingkat kesalahan 0,05 diperoleh yaitu 14. Hal ini dapat disimpulkan bahwa pada tahun $2014 \quad \mathrm{H}_{0}$ diterima dan $\mathrm{H}_{\mathrm{A}}$ ditolak karena $\mathrm{J}_{\text {-hitung }}$ lebih besar dari pada $\mathrm{J}_{\text {-tabel }}$ yaitu $\quad \mathrm{J}_{\text {-hitung }}=43 \geq \mathrm{J}_{\text {-tabel }}=14$ dengan demikian hipotesis diterima. 
Dengan ketentuan sebagai berikut:

$\mathrm{H}_{0} \quad$ : terdapat perbedaan anggaran biaya produksi dengan laporan akuntansi pertanggungjawaban biaya produksi.

$\mathrm{H}_{\mathrm{A}} \quad$ : tidak ada perbedaan anggaran biaya produksi dengan laporan akuntansi pertanggungjawaban biaya produksi.

Tabel 4.3

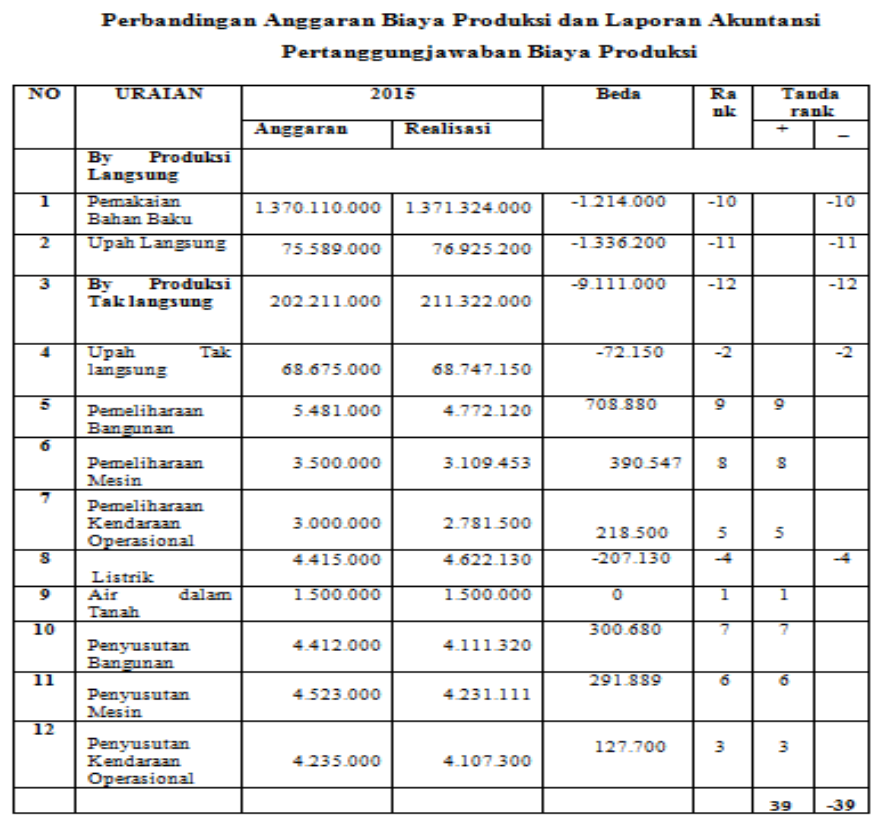

Sumber: diolah oleh penulis

Hal ini dikarnakan besarnya biaya dan kondisi ekonomi yang sedang terjadi pada saat melakukan transaksi. Adapun perbedaan terjadi pada biaya bahan baku, biaya tenaga kerja, listrik, dan biaya lainnya. Namun dari hasil perhitungan pada tabel di atas maka diperoleh nilai terkecil dari perhitungan wilcoxon, nilai terkecil diperoleh pada rank negatif dimana sebesar 19, hal tersebut bisa disimpulkan bahwa yang menjadi $J_{\text {-hitung }}=39$. Sedangkan $n=12$ untuk $\mathrm{J}_{\text {-tabel }}$ diambil dari tabel uji wilcoxon dengan tingkat kesalahan 0,05 diperoleh yaitu 14 . Hal ini dapat disimpulkan bahwa pada tahun $2015 \mathrm{H}_{0}$ diterima dan $\mathrm{H}_{\mathrm{A}}$ ditolak karena $\mathrm{J}_{\text {-hitung }}$ lebih besar dari pada $\mathrm{J}_{\text {-tabel }}$ yaitu $\mathrm{J}_{\text {-hitung }}=39 \geq \mathrm{J}_{\text {-tabel }}=14$ dengan demikian hipotesis diterima.

Dengan ketentuan sebagai berikut:

$\mathrm{H}_{0} \quad$ : terdapat perbedaan anggaran biaya produksi dengan laporan akuntansi pertanggungjawaban biaya produksi.

$\mathrm{H}_{\mathrm{A}}$ : tidak ada perbedaan anggaran biaya produksi dengan laporan akuntansi pertanggungjawaban biaya produksi. 
Tabel 4.4

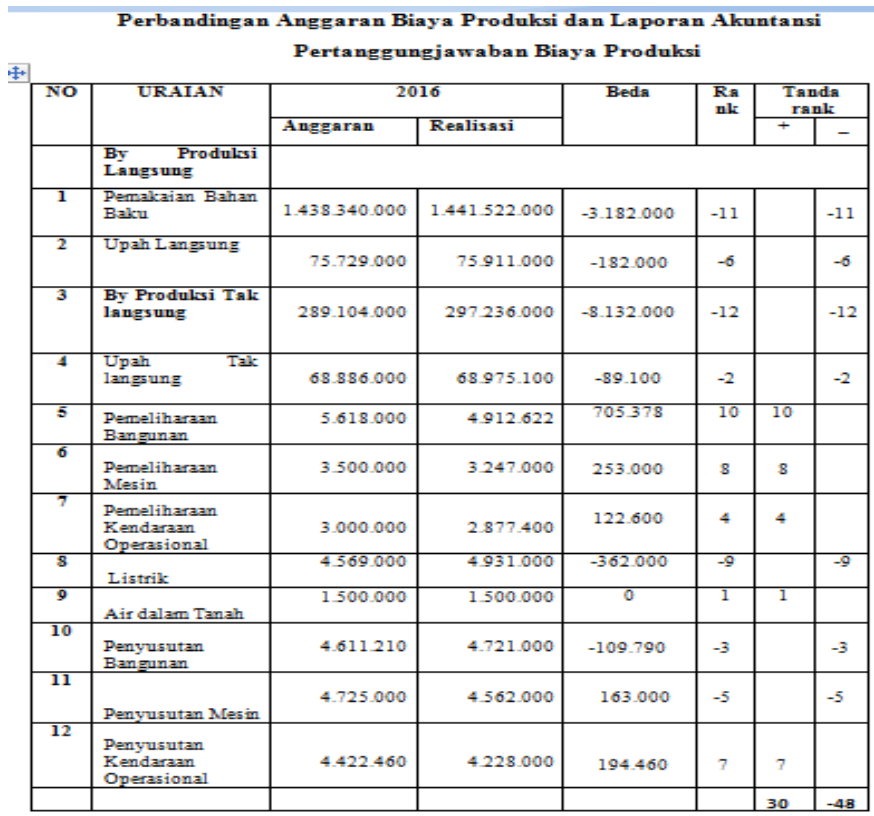

Sumber: diolah oleh penulis

Hasil perhitungan Uji wilcoxon bahwa diperoleh ada beberapa perbedaan anggaran dengan hasil laporan akuntansi pertanggungjawaban yang dilakukan, hal ini dikarnakan banyaknya pemesanan yang meningkat dan banyaknya pemesanan sangat mempengaruhi peningkatan produksi. Biaya untuk lembur tidak dianggarkan sehingga biaya realisasi lebih besar dari yang dianggarkan. Adapun perbedaan terjadi pada biaya bahan baku, biaya tenaga kerja, listrik, dan biaya lainnya. Namun dari hasil perhitungan pada tabel di atas maka diperoleh nilai terkecil dari perhitungan wilcoxon, nilai terkecil diperoleh pada rank negatif dimana sebesar 48 , hal tersebut bisa disimpulkan bahwa yang menjadi $J_{\text {-hitung }}=48$. Sedangkan $n=12$ untuk $J_{\text {-tabel }}$ diambil dari tabel uji wilcoxon dengan tingkat kesalahan 0,05 diperoleh yaitu 14. Hal ini dapat disimpulkan bahwa pada tahun $2016 \mathrm{H}_{0}$ diterima dan $\mathrm{H}_{\mathrm{A}}$ ditolak karena $\mathrm{J}_{\text {-hitung }}$ lebih besar dari pada $\mathrm{J}_{\text {-tabel }}$ yaitu $\mathrm{J}_{\text {-hitung }}=48 \geq \mathrm{J}_{\text {-tabel }}=14$ dengan demikian hipotesis diterima.

Dengan ketentuan sebagai berikut:

$\mathrm{H}_{0} \quad$ : terdapat perbedaan anggaran biaya produksi dengan laporan akuntansi pertanggungjawaban biaya produksi.

$\mathrm{H}_{\mathrm{A}} \quad$ : tidak ada perbedaan anggaran biaya produksi dengan laporan akuntansi pertanggungjawaban biaya produksi. 


\section{BAB V}

PENUTUP

\subsection{Kesimpulan}

Berdasarkan penelitian yang dilakukan pada PT. Gunung Naga Mas Padang mengenai penerapan akuntansi pertanggungjawaban dengan anggaran sebagai alat pengendalian biaya, maka penulis menarik kesimpulan bahwa penerapan akuntansi pertanggungjawaban di PT. Gunung Naga Mas Padang belum memadai karena ada syarat akuntansi pertanggungjawaban belum terpenuhi yaitu pemisahan biaya terkendali dan tidak terkendali tetapi dalam karakteristik akuntansi pertanggungjawaban pada PT. Gunung Naga Mas Padang sudah baik.

Dan pada pengujian uji wilcoxon perbandingan dimulai dari tahun 2013.2014. 2015 dan 2016 yang mana untuk $\mathrm{J}_{\text {-tabel }}$ membandingkannya dengan $\mathrm{J}_{\text {-hitung }}$ bahwa hipotesis diterima. Hal ini diperoleh dari pengujian masing-masing tahun sebagai berikut:

1. Hal ini dapat disimpulkan bahwa pada tahun $2013 \mathrm{H}_{0}$ diterima dan $\mathrm{H}_{\mathrm{A}}$ ditolak, karena $\quad \mathrm{J}_{\text {-hitung }}=32 \geq \mathrm{J}_{\text {-tabel }}=14$, maka hipotesis diterima.

2. Sedangkan tahun $2014 \mathrm{H}_{0}$ diterima dan $\mathrm{H}_{\mathrm{A}}$ ditolak, karena $\mathrm{J}_{\text {-hitung }}=43 \geq \quad \mathrm{J}_{\text {-tabel }}=$ 14 , dengan demikian hipotesis diterima.

3. Namun pada tahun $2015 \mathrm{H}_{0}$ diterima dan $\mathrm{H}_{\mathrm{A}}$ ditolak karena $\mathrm{J}_{\text {-hitung }}=39 \geq \quad \mathrm{J}_{\text {-tabel }}=14$ maka hal ini dapat diartikan hipotesis diterima.

4. Dan pada tahun $2016 \mathrm{H}_{0}$ diterima dan $\mathrm{H}_{\mathrm{A}}$ ditolak karena $\mathrm{J}_{\text {-hitung }}=48 \geq \mathrm{J}_{\text {-tabel }}=14$ berarti hipotesis diterima.

Jadi dapat disimpulkan bahwa hipotesis diterima yaitu terdapat perbedaan anggaran dengan laporan akuntansi pertanggungjawaban biaya produksi

\subsection{Saran}

Selain kesimpulan yang dikemukakan diatas, penulis juga memberi masukan barupa saran kepada perusahaan yaitu :

1. Dalam anggaran maupun laporan akuntansi pertanggungjawaban sebaiknya dilakukan pemisahan biaya-biaya yang dapat dikendalikan maupun tidak dapat dikendalikan oleh manajer karena hanya biaya yang dapat dikendalikan saja yang dapat dimintai pertanggungjawaban.

2. Pimpinan perusahaan sebaiknya melakukan analisis dan koreksi terhadap penyimpangan yang tidak menguntungkan kemudian mengajukan rekomendasi menanggapi penyimpangan yang terjadi.

\section{DAFTAR PUSTAKA}

Agussalim Manguluang, 2013, Statistik. Ekasakti Press, Padang.

Anthony,Robert N. dan Govindaraja, Vijay. 2011. Sistem Pengendalian Manajemen. Jilid I. Jakarta: Salemba Empat.

Carter, William. K, 2009. Akuntansi Biaya Cost Accounting,. Edisi Empat Belas, Penerbit salemba Empat, Jakarta.

Fairul dkk.2015.Analisis penerapan Akuntansi Pertanggungjawaban dengan Anggaran Sebagai Alat Pengendalian Biaya pada PT. Surya Sakti Utama Surabaya.Jurnal Akuntansi UBHARA.ISSN:2460-7762

Hansen, D. R. Mowen. M.M. 2009. Akuntansi Manajerial. Salemba Empat, Jakarta.

Hansen, Don R. dan Maryanne M. Mowen. 2010. Management Accounting: Akuntansi Manajemen. Edisi Ketujuh. Buku 2. Jakarta: Salemba Empat.

Hongren, Charles T dan Datar. 2012. Pengantar Akuntansi Manajemen, Terjemahan Moh Badjuri dan Drs. Kusnedi. Edisi VI. Jakarta: PT. Salemba Empat.

Mulyadi. 2010. Akuntansi Biaya. Yogyakarta: STIE. YPKPN.

Simamora, Henry. 2012. Akuntansi Manajemen, Edisi ketiga. Riau: Star Gate Publisher. 
Stefanly dan Tirayoh.2015.Penerapan Akuntansi Pertanggungjawaban dengan Anggaran Sebagai Alat Pengendalian Biaya pada PT. Gotrans Logistic Cabang Manado.Jurnal Berkala Ilmiah Efisiensi. Volume 15 No.03

Supriyono, R. 2011. Akuntansi Perencanaan dan Pengendalian biaya, serta Pengambilan Keputusan. Yogyakarta: BPFE. 